\title{
THE TRIASSIC INSECT FAUNA FROM ARGENTINA. I. AUCHENORRHYNCHA, MIOMOPTERA AND ENSIFERA
}

\author{
Rafael Gioia MARTINS-NETO ${ }^{1}$ and Oscar \\ Florencio GALLEGO
}

1 Laboratory of Paleontology, Biology Department. Universidade de São Paulo - USP. Campus of Ribeirão Preto. Av. Bandeirantes, 3900, 14040-901 Ribeirão Preto - SP. Brazil. e-mail: mtnsneto@ffclrp.usp.br

2 Catedra de Paleontologia (FACENA - UNNE) and PRINGEPA CONICET. Casilla de Correo 128 (3400) Corrientes - Argentina. e-mail: ogallego@unefcen.edu.ar

Martins-Neto, R.G. and Gallego, O.F. 1999. The Triassic insect fauna from Argentina. I. Auchenorthyncha, Miomoptera and Ensifera. [Insectos triásicos de Argentina. I. Auchenorrhyncha, Miomoptera y Ensifera.] Revista Española de Paleontología, 14(2), 191-202. ISSN 0213-6937.

\begin{abstract}
The present paper describes new fossil insect taxa from the Potrerillos and Los Rastros formations, from Mendoza and La Rioja Provinces respectively of Argentina, both of which are dated as late Middle Triassic to early Late Triassic. Three new genera and five new species are proposed, namely Dysmorphoptiloides acostai $\mathrm{n}$. sp., Argentinocicada magna n. gen. et n. sp., Argentinocicada minuta n. sp., Potrerillia nervosa n. gen. et n. sp. (Auchenorrhyncha) and Miomina mendozina n. gen. et n. sp. (Miomoptera). The genus Notopamphagopsis Cabrera (Ensifera) is reviewed. These insects currently represent the most important documentation of a Triasssic insect fauna from South America.
\end{abstract}

Keywords: Fossil insects, South America Triassic, Auchenorrhyncha, Miomoptera, Ensifera.

\section{RESUMEN}

En este trabajo se describen algunos componentes de la paleoentomofauna triásica de Argentina hallados en las formaciones Potrerillos (Mendoza) y Los Rastros (La Rioja), ambas asignadas al lapso de finales del Triásico Medio al inicio del Triásico Tardío. Se proponen tres nuevos géneros y cinco nuevas especies: Dysmorphoptiloides acostai n. sp., Argentinocicada magna n. gen. et n. sp., Argentinocicada minuta n. sp., Potrerillia nervosa n. gen. et n. sp. (Auchenorrhyncha) y Miomina mendozina $\mathrm{n}$. gen. et $\mathrm{n}$. sp. (Miomoptera). Se brinda la revisión del genero Notopamphagopsis Cabrera (Ensifera). Estos hallazgos representan el registro más importante de insectos triásicos para América del Sur.

Palabras clave: Insectos fosiles, Triásico de América del Sur, Auchenorrhyncha, Miomoptera, Ensifera.

\section{INTRODUCTION}

This paper presents the description of a part of the fossil insect fauna from the Potrerillos and Los Rastros formations, respectively from the Mendoza and La Rioja Provinces of Argentina, both dated as late Middle Triassic to early Late Triassic. Insects of the orders Auchenorrhyncha, Miomoptera and Ensifera are dealt with.

The record of insects in the Triassic of South America is sparse; it has been summarized by Gallego (1997). From the Triassic of Brazil only three species are known: two Auchenorrhyncha, Sanctipaulus mendesi Pinto, 1956 and Prosbolidinella riorastensis Martins-Neto and Rohn, 1996 and one Blattoptera, Triassoblatta cargnini Pinto and Ornellas, 1974. In the Potrerillos Formation, more particularly the stratigraphic level at southern Cerro Cacheuta (Mendoza Province) contains the insects described by Cabrera (1928), Carpenter (1960), Pinto and Purper (1978) and Marquat (1991). For the Los Rastros Formation the only record is a short note by Frenguelli (1948), who mentioned coleopteran elytra, at the well known Ischigualasto locality in San Juan Province. Fuenzalida (1937) and Cecioni and Westermann (1968) cited the presence of undetermined insects from the "Rhaetic" of the Punta Puquin, Los Lobos and Los Molles localities, from the Quebrada del Peral, Province of Central Chile, in strata of the El Puquén Formation (probably equivalent to the Pichidangui Formation, sensu Rivano and Sepulveda, 1991). 
The specimens described in this paper are mainly from the Quebrada del Durazno locality, south of Cerro Cacheuta, (Lujan de Cuyo Department, Mendoza Province, Argentina); they were collected during a field trip in September 1995, by a team formed by the second author and A. M. Zavattieri, A. Menendez, J. Cruz, and A. Acosta. The material is housed in the Paleozoological Collection of the Facultad de Ciencias Exactas, Naturales y Agrimensura de la Universidad Nacional del Nordeste (Corrientes Province, Argentina) under the collection number PZ-CTES. Another specimen was collected from the Gualo locality (La Rioja Province, Argentina) during a field trip in April 1995, by another team formed by the second author and A. Arcucci, C. Forster, C. May, and $\mathrm{R}$. Rogers. This specimen is housed in the Invertebrate Paleontological Collection of the Universidad Nacional La Rioja, under the collection number PULR(I). The terminology and classification adopted here conforms mainly to that of Kukalova-Peck (1991).

\section{GEOLOGICAL ASPECTS}

The insects found in southern Cerro Cacheuta, of Mendoza Province originate from the classic locality named Cacheuta or "Minas de Petroleo" within the upper horizon of the Potrerillos Formation of late Middle Triassic to early Late Triassic age.

In the locality mentioned above, the Potrerillos Formation is represented by the upper $125 \mathrm{~m}$ of strata, since the boundary with the porphyrites from Choiyoi Group of Early Permian to Early Triasssic age, to the Cacheuta Formation boundary, established as early Late Triassic (Stipanicic et al., 1995, fig. 19).

The horizon from which the insects originate is within the rhytmite facies of Morel (1994) that are stratigraphically contained in tabular beds of 20 to $50 \mathrm{~cm}$ thickness. The tuffaceous, argillaceous strata that contain this fauna are claystones and limonitic volcanic shales that are often white to yellowish or grey to greyish. These strata are partly carbonatized and include carbonatized claystone lenses, as well as fossil plant impressions, conchostracans, cuticles and fish scales. They represent a flood plain environment. The thickness of the Potrerillos Formation in this locality is $125 \mathrm{~m}$ (Morel, 1994), i.e. thinner than other outcrops with this sedimentary succession, but characteristic of the marginal zone of the basin. The stratigraphic level containing insects could correspond to paleobotanic strata I and II of Morel (1994) (see Fig. 1). Possibly, the insects of the Order Plecoptera described by Pinto and Purper (1978) and of the Order Ensifera (Notopamphagopsis Cabrera, 1928) originated from this same horizon.

The ensiferans described in this paper come from the Gualo locality of La Rioja Province. They were collected at several levels of the Los Rastros Formation which outcrops extensively in this area. Apart from the specimens mentioned above, several others were also collected, that are currently being studied.
The Los Rastros Formation is $200 \mathrm{~m}$ thick in the Gualo area and is characterized by several sedimentary sequences that are repeated in vertical succession according a cyclicity of the pulsative type. These rhythmites are in ascending order as follows: a) dull sandstones and conglomerates, which matrix varying in color from green to green-yellowish; b) fine dark green sandstones and c) limy grey to dark claystones (Herbst, 1970; Stipanicic and Bonaparte, 1979), which are stratigraphically distributed in packages typically half a meter thick (see Fig. 1). Presently, new data are being collected and analyses made with regard to the sedimentology and paleoenvironmental conditions. The insect fauna is preserved in the clayey sediments.

\section{SYSTEMATIC PALEONTOLOGY}

\author{
ORDER AUCHENORRHYNCHA sensu Evans, 1956 \\ Superfamily CERCOPOIDEA sensu Evans, 1956 \\ Family Dysmorphoptilidae Handlirsch, 1906 \\ Genus Dysmorphoptiloides Evans, 1956
}

Type-species: Dysmorphoptiloides elongata Evans, by original designation.

\section{Dysmorphoptiloides acostai $\mathrm{n}$. sp.}

Fig. 2A

Derivatio nominis: Dedicated to Alberto Acosta, who collected several of the specimens dealt with this paper.

Holotype: PZ.CTES-5772, housed in the Paleozoological Collection of the Facultad de Ciencias Exactas, Naturales y Agrimensura de la Universidad Nacional del Nordeste, Mendoza, Argentina.

Type locality: $300 \mathrm{~m}$ west of Quebrada del Durazno. South of Cerro Cacheuta. Mendoza, Argentina, bands EP I and EP II of Morel (1994).

Type stratum: Upper section of the Potrerillos Formation.

Age: Late Middle Triassic to early Late Triassic.

\section{Diagnosis}

Wing similar to Dysmorphoptiloides elongata Evans, 1956 from the Australian Upper Triassic in the general aspects of the alar venation. RA fused to RP after $\mathbf{m}$-cu level and before the $\mathbf{r}-\mathbf{m}$ level. MP1+2 unforked.

\section{Description}

Forewing fragment with $10 \mathrm{~mm}$ of length preserved. Parallel RA quite parallel to the costal margin, deflecting toward the apex at the emarginated portion of the costal margin, forward the limit of the apical margin. RP and RA fused at the boundary of the apical margin. RA+RP fuses to MA1 +2 by a cross vein occurring posterior to the RA/RP fusion. MP long, slightly curved, forking before the RA/RP fusion. $\mathbf{M} 1+2$ unforked. $M 3+4$ forks at the level of $\mathbf{r}+\mathbf{m}$. CuA long, straight, forking after the RA/RP fusion. CuA 


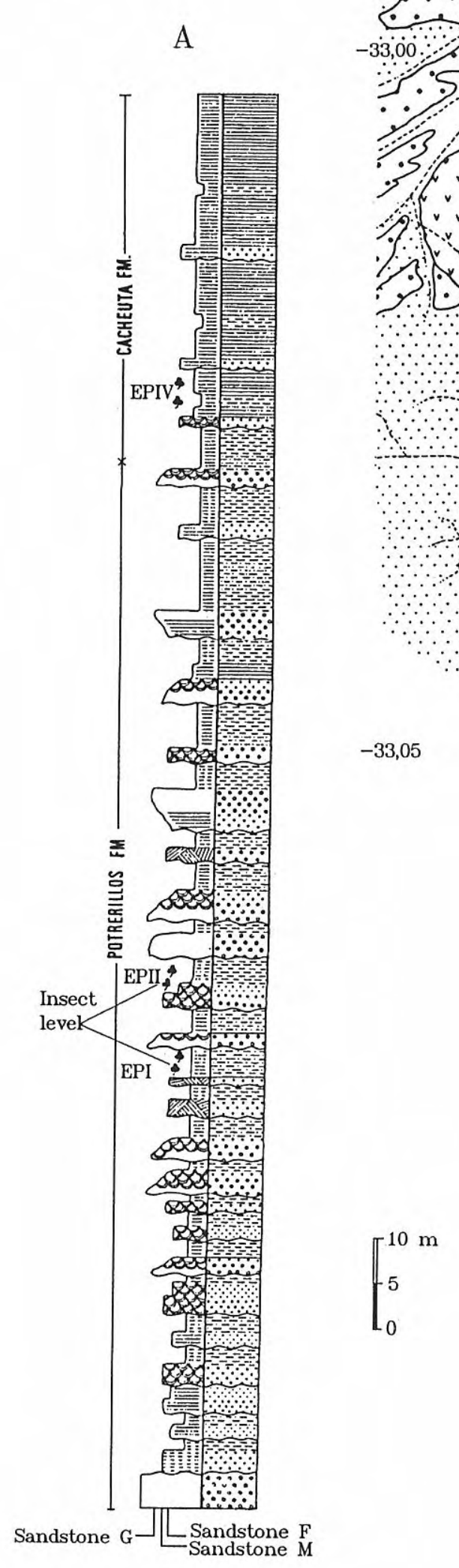

Puesto Miguel profile
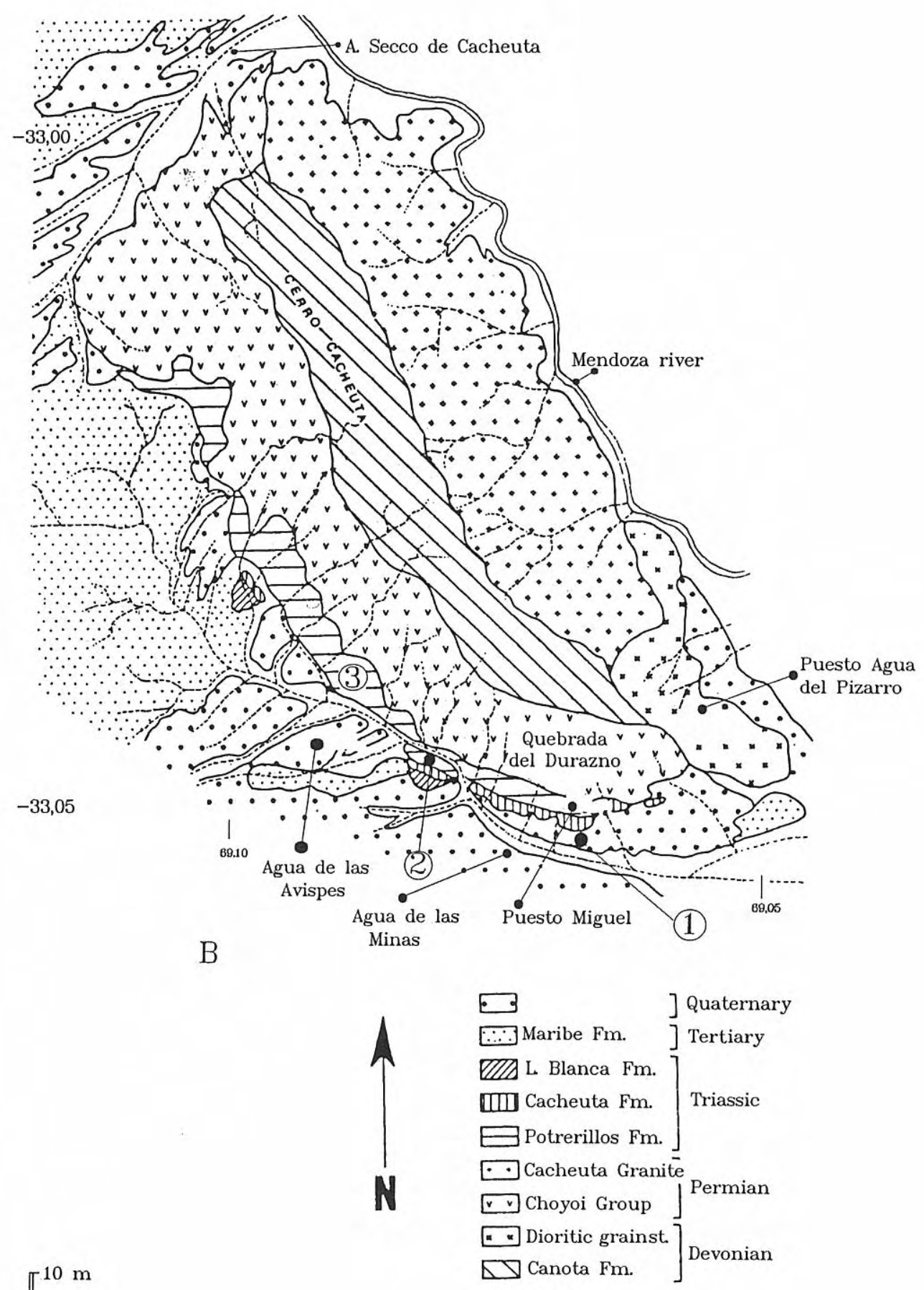

(1) Profile

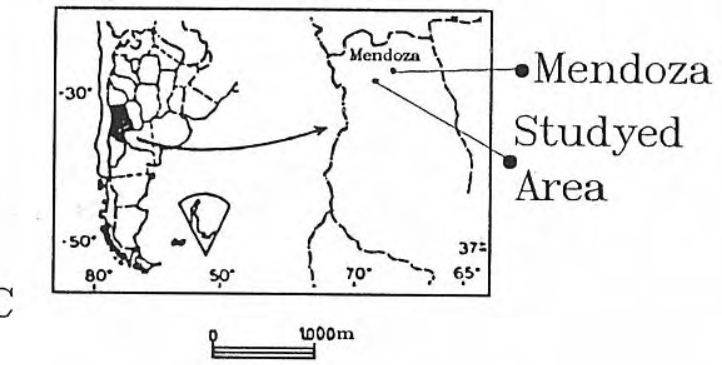

Figure 1. A Puesto Miguel profile and position of the collected specimens (after Morel, 1994, figs. 1-3). B. Geological map of the Cerro Cacheuta region. C. Geographic index map. 
longer than $\mathbf{C u A 2}$, curved. MP and $\mathbf{C u A}$ are linked by a cross-vein ( $\mathbf{m}-\mathbf{c u})$ positioned before the forking of $\mathbf{C u A}$ and after the RA/RP fusion. CuP partially preserved, parallel to CuA. The entire surface of the wing is rugose, with a homogeneously granular surface (Fig. 2A).

\section{Discussion}

Dysmorphoptiloides acostai $\mathrm{n}$. sp. is very similar to the specimen C614 figured by Evans (1956, fig. 17D) named as $D$. elongata, principally attributable to RA/RP fusion, not found in other specimens (for example Evans, 1971, figure 2). D. acostai $\mathrm{n}$. sp. is separated from $D$. elongata Evans by having MP1+2 unforked, which occurs in Dysmorphoptila liasina Handlirsch, 1906, described from the Lower Jurassic of England. However, the remaining venational pattern is dissimilar. Dysmorphoptila notodon Scherbakov, 1988, described from the Jurassic of Mongolia, have M3+4 unforked. The same venational pattern occurs in Mesatracis reducta Bekker-Migdisova, 1949, described from the Lower Jurassic of Central Asia. Dysmorphoptiloides parva Evans, 1956 from the Upper Triassic of Australia and Tennentsia protuberans Riek, 1976 from the Upper Triassic of Africa are different from $D$. acostai n. sp. in having a significantly shorter apex. D. acostai $\mathrm{n}$. sp. and D. elongata Evans are morphologically similar, suggesting perhaps a reliable cronostratigraphic index species for correlation between the classic sediments of Mt. Crosby, and the Ipswich "Series", both from the Australian Upper Triassic, and the Potrerillos Formation of the Upper Triassic in Argentina.

\section{Family Scytinopteridae Handlirsch, 1906 Argentinocicada $\mathrm{n}$. gen.}

Type-species: Argentinocicada magna n. sp., by present designation.

Derivatio nominis: Argentina, from which the material originates, and cicada, from Cicadidae.

\section{Diagnosis.}

Wing similar to Tipuloidea Wieland, 1925 in the general aspect of the venation but with $\mathbf{R A} 3+\mathbf{4}$ unbranched and MP2 and MP4 branched; MP3 originates far from the discal cell and $\mathbf{m}$-cua not aligned with the discal cell and MP1.

\section{Discussion}

Tipuloidea Wieland, 1925 was one of the first insect genera described from the Triassic of Argentina. Despite the inappropriate name, in which a slight modification refers to a superfamily of nematocerous Diptera, and the incorrect original designation of a dipteran rather than an Auchenorrhyncha, several other problems bedevil this historically important material. In his original draft (Wieland, 1925, figs. 2, 3) there is no indication of $\mathbf{C u A}$ prolongation, linking it a $\mathbf{C u P} ; \mathbf{R A}$ is slightly curved; RP is longer and parallel to $\mathbf{R A}$; and $\mathbf{C u P}$ and $\mathbf{C u A 2}$ are distally fused (see figure $2 \mathrm{~F}$ ). In another paper, Wieland
(1926, figure 2) drafts the same specimen differently, in which the CuP is not distally fused with $\mathbf{C u A 2}$; the $\mathbf{C u A}$ prolongation is not linked to the $\mathbf{C u P}$ base; $\mathbf{R A}$ is notably sigmoid and there is an extra branch of MP4 (see figure 2D). Tillyard (1925) who is noted for the correct classification of the same specimen, redrew it but neglected the extra branch of MP4 without discussing this feature (see figure $2 \mathrm{~F}$ ). With the discovery of new material we suggest that it belongs to the same above genus. Despite the evident inconsistency of the published drawings, a series of structural differences readily justifies generic separation. Argentinocicada n. gen. differs from Tipuloidea Wieland by having RA3+4 unbranched and parallel to $\mathbf{R P}$, in which distal extremities deflect at an angle approximately $45^{\circ}$ forward the costal margin. MP2 is branched, from which originate the two branches MP2A and MP2B, both of which are the same size, forking at the mid-length of MP2. MP3 originates far from the discal cell, unlike Tipuloidea Wieland, which has its origin in the discal cell. MP4 is branched, with MP4A parallel to MP3, and MP4b convergent to CuA1, unlike Tipuloidea Wieland which does not have MP4 branched (except in the Wieland version of 1926). However, in the present interpretation, MP4b is regarded as sigmoid, divergent of CuA1, with both branches forming the base of the discal cell, unlike Argentinocicada n. gen. where MP4A forms the upper part and MP4B the lower part of the discal cell. Additionally, Argentinocicada n. gen. does not have mcua aligned with the discal cell, and MP1 is found as in Tipuloidea Wieland. In Argentinocicada n. gen. m-cua is aligned with a nodal line that follows the costal margin, the distal part of which provides a branch of RA3+4.

\section{Argentinocicada magna $\mathrm{n}$. sp. Figs. 2C, 4A}

Derivatio nominis: From Latin, big, alluding to the large size of the species.

Holotype: PZ-CTES-5729, housed at the Paleozoological Collection of the Facultad de Ciencias Exactas, Naturales y Agrimensura, de la Universidad Nacional del Nordeste. Corrientes Province, Argentina.

Type locality, type stratum and age: As for Dysmorphoptiloides acostai $\mathrm{n}$. sp.

\section{Diagnosis}

As for the genus. Wing length approximately $30 \mathrm{~mm}$, nearly three times longer than wide. Costal area broad at wing base.

\section{Description}

Forewing $28 \mathrm{~mm}$ in length and $10 \mathrm{~mm}$ wide. Costal area broad at wing base, narrowing slightly towards the apex. RA long, slightly curved, branching after half the distance to the wing apex, branching into $\mathbf{R A 1 + 2}$ which is relatively long. RA3+4 intersects the costal margin near the apical margin. RP long and its origin occurs approximately at the basal $1 / 3$ 

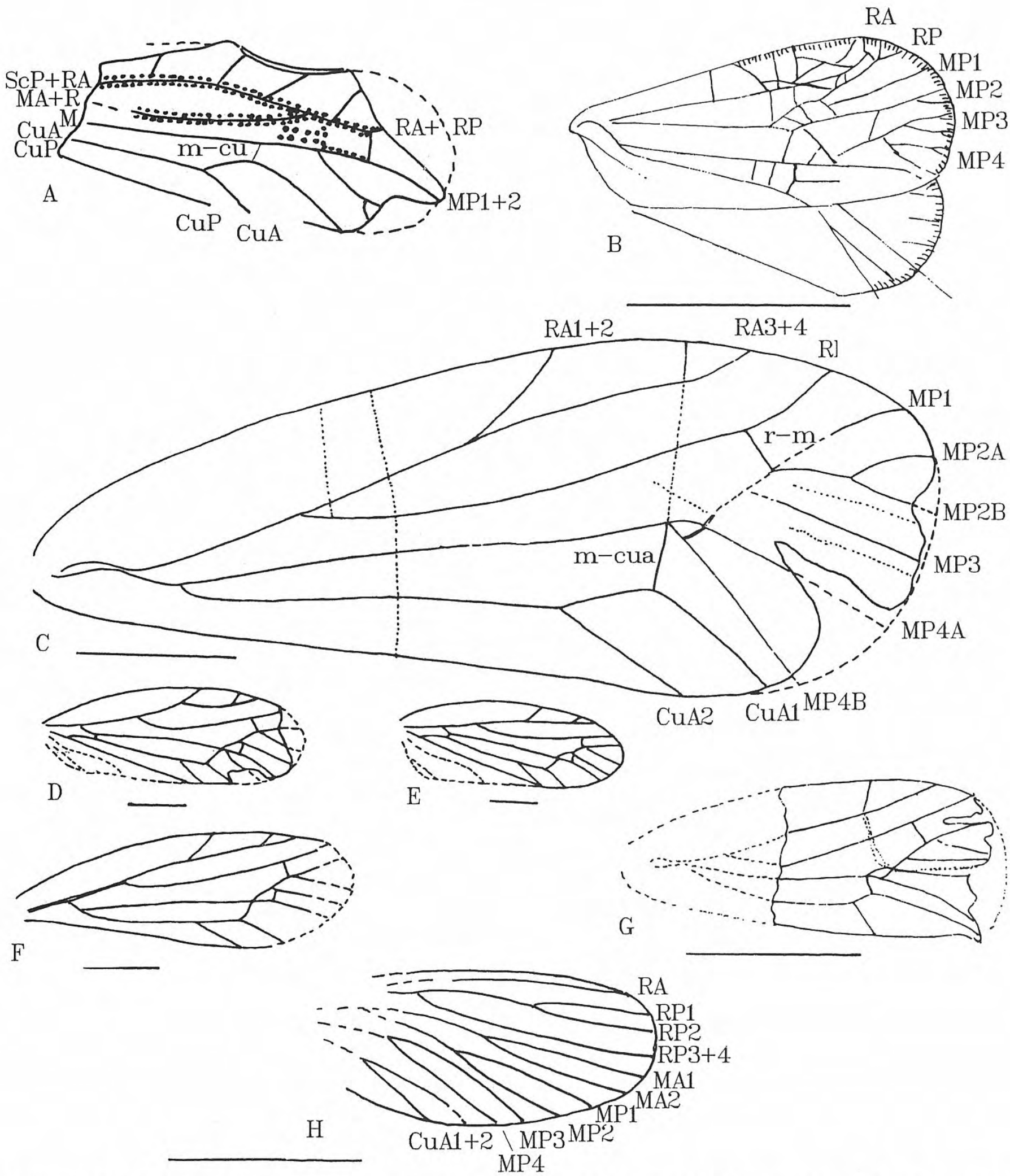

Figure 2. A. Forewing of Dysmorphoptiloides acostai n. sp., holotype. B. Forewing of Potrerillia nervosa n. sp., holotype. C. Forewing of Argentinocicada magna n. sp., holotype. D. Forewing of Tipuloidea rhaetica Wieland, redrawn from Wieland (1925, fig. 2). E. Forewing of Tipuloidea rhaetica Wieland, redrawn from Wieland (1926, fig. 2). F. Forewing of Tipuloidea rhaetica Wieland redrawn from Tillyard (1925, fig. 1). G. Forewing of Argentinocicada minima n. sp., holotype. H. Forewing of Miomina mendozina n. sp., holotype. Scale bar $5 \mathrm{~mm}$. Terminology: CuA, $\mathbf{C u P}$, anterior and posterior cubitus, respectively; MA, MP, anterior and posterior media, respectively; RA, RP, anterior and posterior radial, respectively; ScP, posterior subcostal; cua-cup, anterior cubital-posterior cubital cross-vein; m-cu, medial-cubital cross-vein; r-m, radial-medial cross-vein. 
of the wing length, following in parallel fashion the RA3+4 vein, deflecting apically toward the margin of both costal and apical areas. $\mathbf{M}$ long, originating in the central region of the wing, diverging into four secondary branches: MP1 curved; MP2 two branched (MP2A and MP2B), all of similar size; MP3 straight and MP4 two-branched (MP4A and M4B), both long and straight. Discal cell small, formed anteriorly by the MP4a base and posteriorly by the MP4b base, connected by an aligned cross-vein with the extension of MP1. MP3 does not form the discal cell. MP4a parallel to both MP3 and MP4B, and convergent to CuA1. r-m relatively long, placed in the $\mathbf{M P 1 + 2}$ fork. CuA long, slightly divergent to $\mathbf{M}$, distally forked. CuaA1 curved, deflecting toward the apical margin, convergent to MP4b, but not fused to it. CuA2 shorter, straight, attaining the anal margin near the boundary of the apical margin. m-cua long, straight, oblique to the anal margin; the anterior portion occurs within the $\mathbf{M}$ fork, an extension of which forms a nodal line that reaches the costal margin, forming a false RA fork (Fig. 2C).

\section{Discussion}

In addition to generic characters already discussed, Argentinocicada magna n. sp. differs from Tipuloidea rhaetica Wieland, 1925 , by having a greater length (28 $\mathrm{mm}$ ) and a greater length/wide ratio: approximately 3 in Argentinocicada magna and 2.5 in Tipuloidea rhaetica. Argentinocicada magna n. sp. also possesses a relatively longer costal area.

\section{Argentinocicada minima n. sp.} Figs. 2G, 4B-C

Derivatio nominis: From Latin, small, alluding to the small size of the species.

Holotype: PZ-CTES n 5776 (Figs. 2G, 4C), housed at the Paleozoological Collection of the Facultad de Ciencias Exactas, Naturales y Agrimensura de la Universidad Nacional del Nordeste at Corrientes, Argentina.

Suplementary specimen: PZ-CTES-5733 (Fig. 4B). Housed in the same institution as above.

Type locality, type stratum and age: As for Dysmorphoptiloides acostai $\mathrm{n}$. sp.

\section{Diagnosis}

Wing similar to Argentinocicada magna n. sp. in general venational aspect, but much smaller. Length approximately $15 \mathrm{~mm}$; width approximately $7 \mathrm{~mm}$. CuA1 relatively longer.

\section{Description}

Forewing apical fragment $7 \mathrm{~mm}$ in length and $7 \mathrm{~mm}$ wide. Costal area narrowing towards the apex. RA long, slightly curved. RA3+4 connects to the costal margin near the boundary of the wing apical margin. RP long, straight, rather parallel to RA. M with four secondary branches: MP1 curved; MP2 shorter; MP3 parallel to posterior margin of the wing and MP4 with two long branches (MP4a and MP4b). Discal cell small, formed anteriorly by the MP4a base and posteriorly by the MP4b base, linked by a crossvein aligned with the MP1 extension. MP3 does not belong to the discal cell. MP4a parallel to MP3 and MP4b, convergent to $\mathbf{C u A 1}$. r-m relatively long, occurring anterior to the MP1+2 fork. CuA long, distally forked: CuA1 curved, long, deflected towards the anal margin. $\mathbf{C u A} 2$ shorter, quite straight, reaching the anal margin at $1 / 3$ of the distance to the wing apex. m-cua relatively short, oblique to CuA2 of which the anterior part lies in the $\mathbf{M}$ fork (Fig. 2G).

\section{Discussion}

Argentinocicada minima n. sp. differs of A. magna $\mathrm{n}$. sp., found in the same sediments, by a notably smaller size. Additionally, A. minima n. sp. has a truly distal bifurcation in the RA vein and an absence of a nodal line linking $\mathbf{m}$-cua to the costal margin. The $\mathbf{m}$-cua crossvein is more oblique and smaller than $\mathbf{r}-\mathbf{m}$, unlike $A$. magna $\mathrm{n}$. sp. with its m-cua quite vertical and longer than $\mathbf{r}-\mathbf{m}$. Other differences such as an unbranched MP2, relatively longer $\mathbf{C u A} 2$ and MP4a horizontal, are characteristics that clearly distinguish this taxon from the other species of Argentinocicada.

\section{Potrerillia n. gen.}

Type-species: Potrerillia nervosa n. sp., by present designation.

Derivatio nominis: Alusive to Potrerillos, local stratigraphic unit.

\section{Diagnosis}

Forewing with the radial area bearing rich cross veined venation forming a mosaic of cells. $\mathbf{M}$ with four principal secondary branches, each of which is dichotomous. CuA long and straight terminating at the anal margin apically.

\section{Discussion}

Forewing similar to Permopibrocha Martynov, 1936, of the the Russian Lower Permian, in its general venational aspect and principally by having a similar network of cross-veins and by a dichotomizing $\mathbf{M}$. However, Potrerillia n. gen. differs from Permopibrocha by having cross-veins in the subcostal area and a long and straight cubital vein. In this respect, Potrerillia n. gen. is similar to Permobrachus Evans, 1943, described from the Australian Upper Permian, but differs from it in all other observed aspects. The large number of cells and rich venation in the subcostal area are characters found in Mesocixiella Martynov, 1937, described from the Russian Lower Jurassic, which includes a long cubital vein. Potrerillia n. gen. differs, however, by having a larger number of $\mathbf{M}$ branches. The classification in the Family Scytinopteridae is based on the presence of accessory veins. These accessory veins occur in all of the constituent genera and also in Orthoscytina Tillyard, 1926, described from the Australian Permian, 


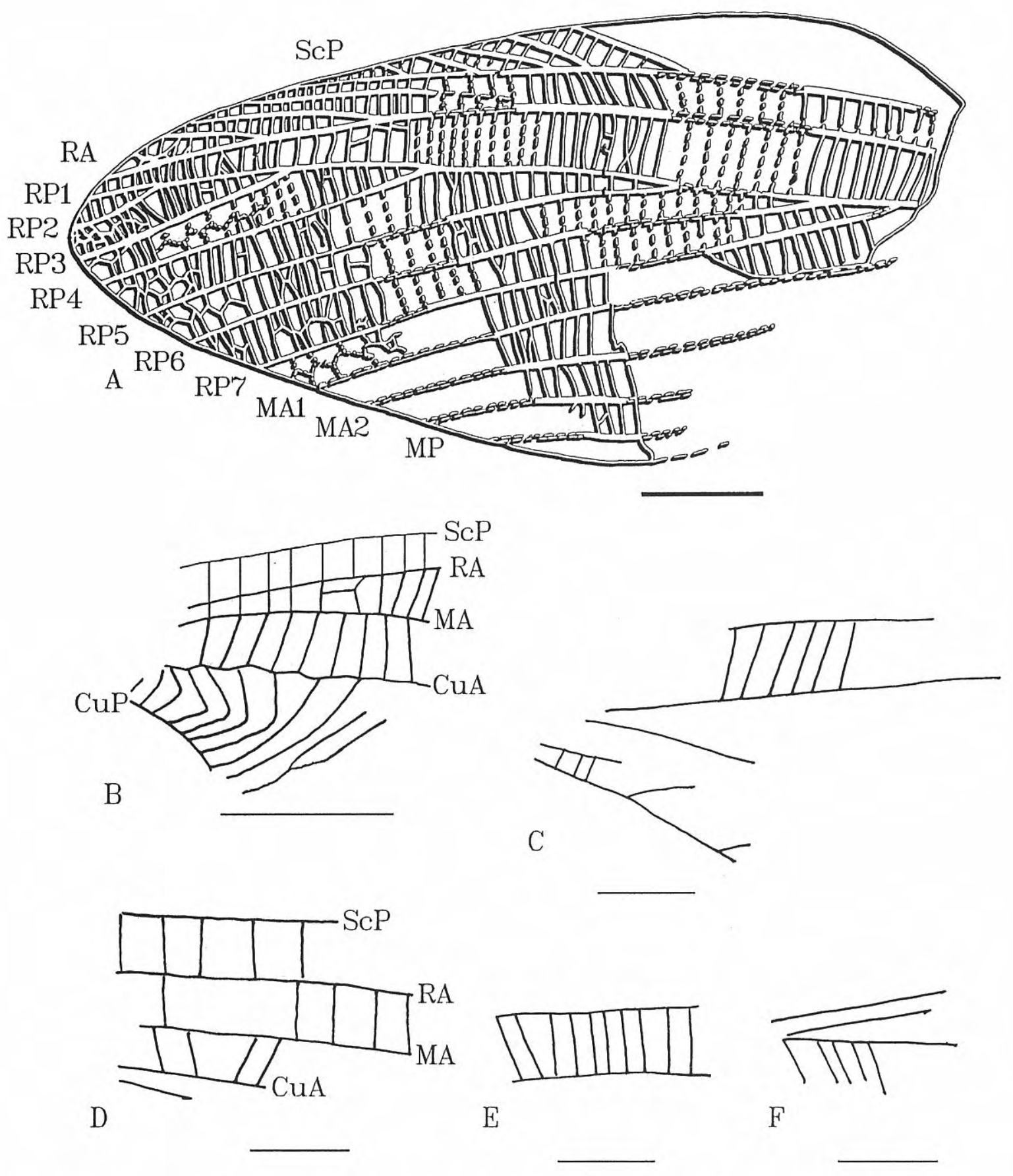

Figure 3. A. Forewing of Notopamphagopsis bolivari Cabrera, 1928, drawn from holotype. B-F. Notopamphagopsis ? sp. wing fragments. Terminology see Fig. 2. Scale bar $5 \mathrm{~mm}$.

Mesodipthera Tillyard, 1922, described from the Australian Upper Triassic, and Triassoscytinops Evans, 1956, also from the Australian Triassic.

\section{Potrerillia nervosa n. sp.}

Figs. 2B, 5A

Derivatio nominis: Referring to the high number of accessory veins.

Holotype: PZ-CTES-5728, housed at the Paleozoological
Collection of the Facultad de Ciencias Exactas, Naturales y Agrimensura de la Universidad Nacional del Nordeste at Corrientes, Argentina.

Type locality, type stratum and age: As for Dysmorphoptiloides acostai $\mathrm{n}$. sp.

\section{Diagnosis}

As for the genus. Forewing length around $8 \mathrm{~mm}$.

\section{Description}

Forewing $7.8 \mathrm{~mm}$ long. Costal and apical margins very 
corrugated. Subcostal area relatively wide, filled by several cross-veins and accessory veins. RA long, distally deflected, often broken by cross-veins. RP short, originating near the apex. M with four principal secondary branches: MP1, MP2 and MP3, all of which have marginal dichotomies; MP4 with four secondary dichotomies, all possessing supplementary marginal dichotomies. CuA long, straight, terminating at the anal margin apically. CuP divergent from $\mathrm{CuA}$ and reaching the anal margin beyond half the distance from the wing base to apex (Fig. 2B).

\section{ORDER MIOMOPTERA Martynov, 1927 \\ Family indeterminate \\ Miomina n. gen.}

Type-species: Miomina mendozina n. sp., by present designation.

Derivatio nominis: Indicative of the order Miomoptera.

\section{Diagnosis}

Forewing with RA and RP3+4 unforked; CuP and AA forked.

\section{Discussion}

This specimen differs from all known genera by having $\mathbf{C u P}$ and $\mathbf{A A}$ forked, and by RA and RP3+4 unforked. Single RA and RP3+4 occur in some species of the genus Delopterum Sellards, 1909, such as $D$. incertum Martynova, 1958 (Upper Permian of Russia) and D. sinuosum Kukalova-Peck,1991 (Fig. 6.26; Lower Permian of the Czech Republic). In Palaeomantis schmidti Handlirsch, 1904 (Lower Permian of Russia) $\mathbf{R A}$ is forked although RP3+4 is single; in all above mentioned species CuP is unforked. Tychtodelopterum relictum Martynova, 1958 (Upper Permian of the Kuznetsk Basin, Russia) has a RA single and $\mathbf{C u P}$ forked, but four bifurcations in RP (RP1 to RP4). This cluster of characters only occurs in Miomina n. gen. In consequence, it is proposed that a new genus be created for the Argentine material.

\section{Miomina mendozina $\mathrm{n}$. sp.}

Figs. 2H, 5B

Derivatio nominis: From Mendoza, the province from which the material originates.

Holotype: PZ-CTES-5731, housed in the Palaeozoological Collection of the Facultad de Ciencias Exactas, Naturales y Agrimensura de la Universidad Nacional del Nordeste at Corrientes, Argentina.

Type locality, type stratum and age: As for Dysmorphoptiloides acostai $\mathrm{n}$. sp.

\section{Diagnosis}

As for the genus.

\section{Description}

Preserved forewing length $8 \mathrm{~mm}$. The base and the costal margin of the wing are not preserved. RA long, unforked, terminating at the costal margin near the apex. RP with two principal branches: $\mathbf{R P 1}+\mathbf{2}$ dichotomizing into two relatively long branches: RP1 and $\mathbf{R P 2}$ and $\mathbf{R P 3}+\mathbf{4}$ which is unbranched, and reaches the wing apex. MP forks anteriorly to the level of the $\mathbf{R P 1}+\mathbf{2}$ forks, near half of the distance to the wing apex. MP1+2 and MP3+4 are longer than both RP1 and RP2. CuA dichotomizes shortly anterior to the MP fork, resulting in two branches (CuA1 and $\mathbf{C u A 2}$ ) slightly shorter than both $\mathrm{MP1}+2$ and $\mathrm{MP} 3+4$. CuP forks anteriorly of the RP1+2 and RP3+4 forks, and forks into two long branches (CuP1 and CuP2) that are longer than RP, MP and $\mathbf{C u A}$. AA forks shortly anterior of the $\mathbf{C u P}$ forks, dichotomizing into two branches of similar size to the RP1 and RP2 ones. The wing surface is covered by a fine homogeneous granulation (Fig. 2H).

\section{Discussion}

The combination of characteres of Miomina mendozina $\mathrm{n}$. sp. is unique, distinguishing it from all described species of Miomoptera. Despite the description of a nymph from the same region, Triasseuryptilon acostai (Marquat) Storozhenko, 1997 (not the Miomoptera of Marquat, 1991, but the Grylloblattida of Storozhenko, 1997), it is virtually impossible to assimilate it with the material described here. Although the known adult specimens are morphologically close to the genera Palaeomantis Handlirsch, 1904 and Delopterum Sellards, 1909, they can be separated morphologically from Miomina mendozina n. sp., which justifies its new taxonomic status.

\section{ORDER ENSIFERA sensu Martins-Neto, 1991 Family Haglidae sensu Gorochov, 1995 Notopamphagopsis Cabrera, 1928}

Type-species: Notopamphagopsis bolivari Cabrera, 1928, by original designation.

\section{Diagnosis}

Similar to Apsataboilus Gorochov, 1990a, from the Upper Mesozoic of Eastern Transbaikalia by having four secondary branches of $\mathbf{S c P}$, differing however by having seven branches of RP (five in Apsataboilus Gorochov) and a narrower costal field. Distal part of MA and MP veins as for Apsataboilus Gorochov.

\section{Discussion}

Notopamphagopsis is very similar in all preserved venational aspects to the Russian genus Apsataboilus described from the Upper Cretaceous of Transbaikalia, and differs only in the presence of additional RP secondary branches.

\section{Notopamphagopsis bolivari Cabrera, 1928}

$$
\text { Fig. 3A }
$$

*1928 Notopamphagopsis bolivari Cabrera, 372, figs. 1 and 2. 

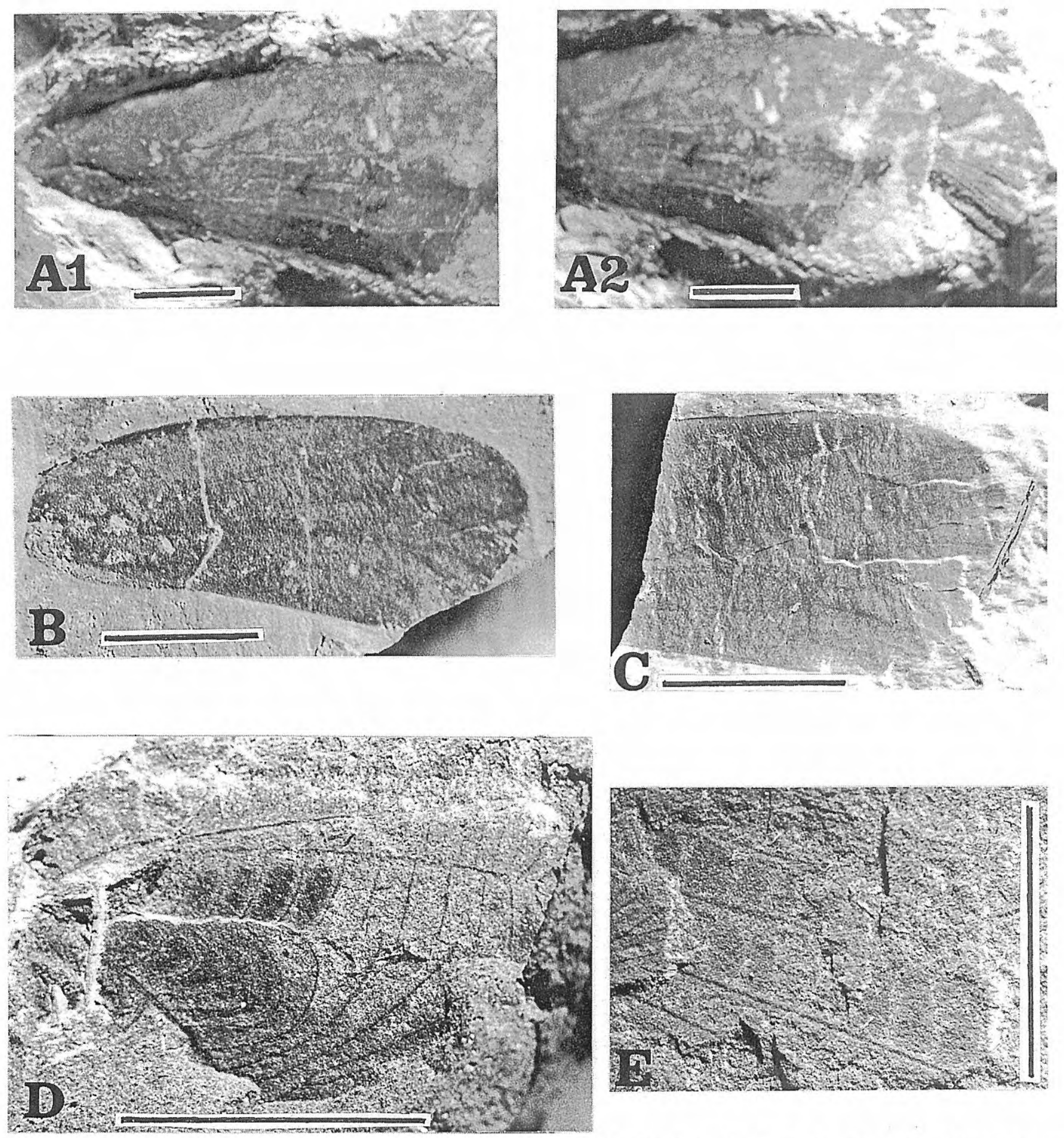

Figure 4. A. Argentinocicada argentina n. sp., holotype, respectively the basal part (A1) and the apical part (A2) of the same specimen. B-C. Argentinocicada minima n. sp., respectively a complementary material (B) and the holotype (C). D-E. Notopamphagopsis sp, isolated fragments. Scale bar $5 \mathrm{~mm}$.

1939 Notopamphagopsis bolivari Cabrera; Zeuner, 18.

1962 Notopamphagopsis bolivari Cabrera; Rohdendorf, 201.

1968 Notopamphagopsis bolivari Cabrera; Sharov, 51.

1991 Notopamphagopsis bolivari Cabrera; Martins-Neto, 26.

1992 Notopamphagopsis bolivari Cabrera; Carpenter, 168. 1995 Notopamphagopsis bolivari Cabrera; Gorochov, 137. 1997 Notopamphagopsis bolivari Cabrera; Gallego, 511.
Holotype: MLP N $\mathrm{N}^{\circ} 4354$, housed in the Departamento de Paleontologia, Invertebrados, Museo de La Plata, Argentina.

Type locality: Cerro Cacheuta, Mendoza. Argentina (possibly the same horizon as EP I and EP II of Morel, 1994).

Type stratum: Potrerillos Formation.

Age: Late Middle Triassic to early Late Triassic. 

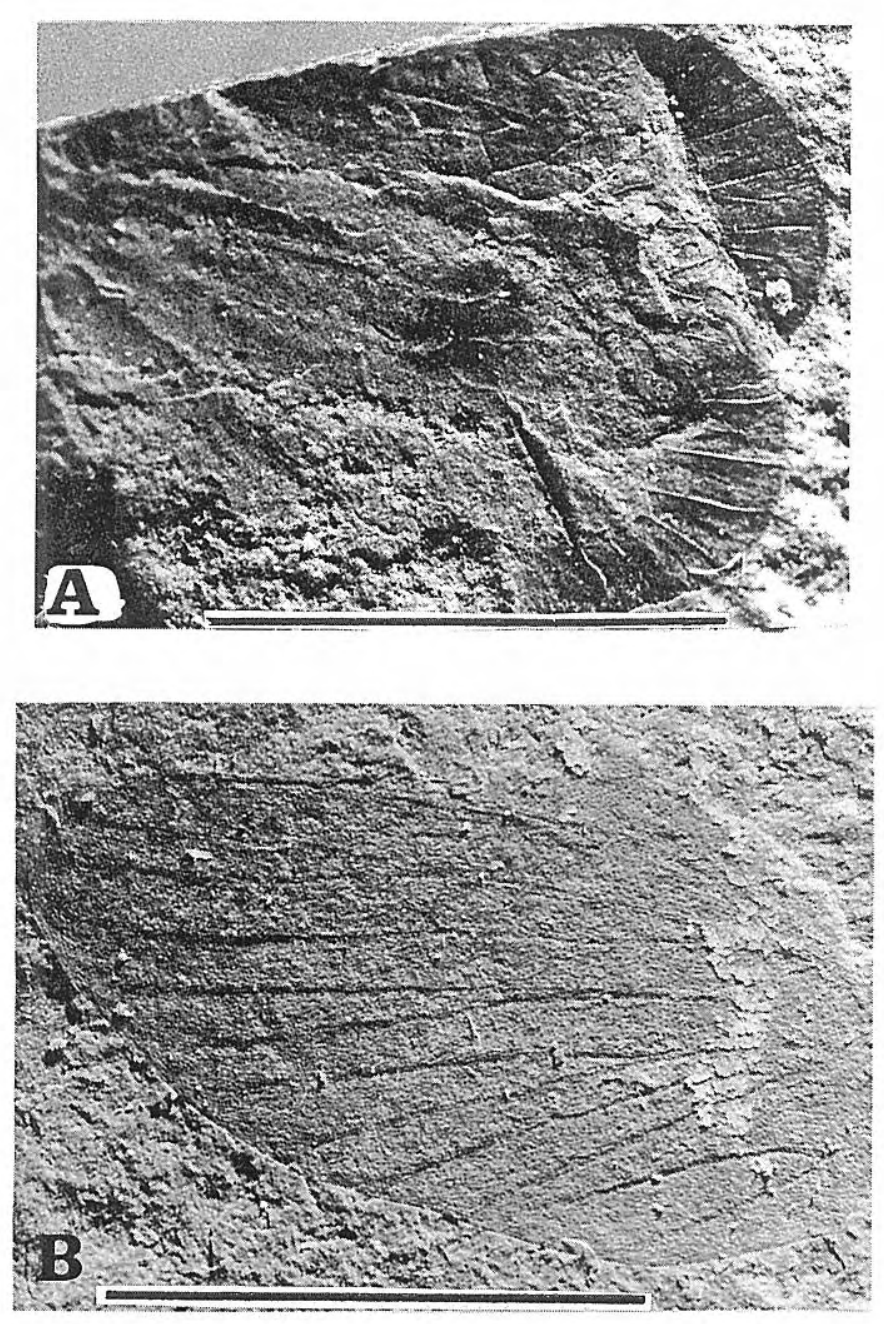

Figure 5. A. Potrerillia nervosa n. sp., holotype. B. Miomina mendozina $\mathrm{n}$. sp., holotype. Scale bar 5 $\mathrm{mm}$.

\section{Diagnosis}

As for the genus.

\section{Description}

Preserved apical part of forewing length $36 \mathrm{~mm}$. Costal area wide, narrowing toward the apex. ScP long, terminating at the costal margin near the apex. Costal field filled by several cross-veins and an archedictyon. RA long, fourbranched, parallel to ScP. RP seven-branched. MA1, MA2 and MP preserved only distally, all which are parallel to RP7. Several cross-veins traverse the wing, forming rectangular cells and archedictions in the apical region.

\section{Remarks.}

This wing fragment is very similar to several haglid taxa, especially the genus Prophalangopsis, including the Tettavidae. The apical arrangement of the secondary branches of RA resembles Apsataboilus sibiricus Gorochov, 1990a, differing by the number of RP branches: seven in Notopamphagopsis bolivari, five in Apsataboilus sibiricus as well as in several related species of Aboilus Martynov.
Notopamphagopsis? sp. Fig. 3B-F

Material: PULR(I)- 223, housed in the Invertebrate Palaeontological Collection, Universidad Nacional de La Rioja, Argentina.

\section{Locality: Gualo, La Rioja Province, Argentina.}

\section{Description}

Forewing basal fragment of a male specimen. RP and MP slightly divergent with six preserved cross-veins. MP somewhat curved. CuA poorly preserved and the area between MP and $\mathbf{C u A}$ with cross-veins relatively long, forming squarish cells, relatively homogeneous in both size and form. Cubital area with eleven cross-veins, all which are long; the first ones are notably curved, forming the harp of a stridulatory apparatus. CuP partially preserved (Fig. 3B).

\section{Remarks}

This specimen probably belongs to the genus Notopamphagopsis. However, its venation is very similar to several genera such as Hagla Giebel, 1856, Aboilus Martynov, 1925, Archihagla Sharov, 1968, Isfaroptera Martynov, 1937, Afrohagla Gorochov, 1990b and several related genera. Other fragments found in the same area (Figs. 3C, D, E and F) probably also belong to Notopamphagopsis.

\section{ACKNOWLEDGMENTS}

We thank to Dr. Ana Maria Zavattieri (IANIGLA/CRICYT, Argentina) for important suggestions regarding the local stratigraphy, and Lic. Andrea Arcucci (Museo de Paleontologia, Universitad Nacional de La Rioja) for field assistance. We also acknowledge Drs. Catherine Forster (State University of New York at Stony Brook) and Cathleen May (USDA United States Agriculture Department-Forest Service) from the Project "El Contexto del Origen de los Dinosaurios: Paleontología y Paleoecología de la Formación. Los Rastros, Triásico Medio de La Rioja", National Geographic Society (Grant 5317-94). Dr. Augusto J. Menéndez, Lic. Jorge Cruz and Alberto Acosta (Mendoza, Argentina), are thanked for their collaboration and friendship. We are grateful to Dr. Rafael Herbst (PRINGEPA/CONICET) for criticisms and suggestions, to Dr. Alberto Riccardi (Museo de La Plata, Argentina) for permission to see the types housed in his Institution, and to Dr. Robert Wagner (Consejo de Redacción de la Revista Española de Peleontología), for correction of the English. Special thanks are due to Dr. Conrad Labandeira (National Museum of Natural History, Smithsonian Institution Department of Paleobiology) and Dr. A. Gorochov (Zoological Institute - St. Petersburg, Russia) for criticisms, suggestions and remarks. This paper is a contribution to IGCP Project 381, South Atlantic Mesozoic Correlations. 


\section{REFERENCES}

Becker-Migdisova, E. E. 1949. Mesozoic Homoptera of Middle Asia. Trudy Paleontologicheskogo Instituta Akademia Nauk, SSSR, Lenningrad, 22, 1-68.

Cabrera, A. 1928. Un segundo Ortóptero de Triásico Argentino. Revista Española de Entomologia, 4, 371373.

Carpenter, F. M. 1960. A Triassic odonate from Argentina. Psyche, 76, 418-425.

Carpenter, F. M. 1992. Hexapoda. In: Treatise of Invertebrate Paleontology. (Ed. R. L. Kaesler). Geological Society of America and University of Kansas, Boulder (Colorado). Part R. Arthropoda 4. Vol. 3-4, 655 pp.

Cecione, G. and Westermann, G. E. G. 1968. The Triassic/Jurassic marine transition of coastal Chile. Pacific Geology, 1, 41-75.

Evans, J. W. 1943. Two intersecting Upper Permian Homoptera from New South Wales. Transactions of the Royal Society South Australia, 67, 7-9.

Evans, J. W. 1956. Palaeozoic and Mesozoic Hemiptera (Insecta). Australian Journal of Zoology, 4, 165-168.

Evans, J. W. 1971. The Periods of origin and diversification of the Superfamilies of the Homoptera - Auchenorrhyncha (Insecta) as determined by study of the wings of Paleozoic and Mesozoic fossils. Proceedings of the Linnean Society of London, 175, 171-183.

Frenguelli, J. 1948. Estratigrafia y edad del llamado "Rético" en la Argentina. Anales de la Sociedad de Estudios Geográficos, Buenos Aires, 8, 159-310.

Fuenzalida, H. 1937. El Títico en la costa de Chile Central. Ministerio de Fomento, Departamento de Minas y Petroleo, Santiago, 6 (65), 739-747.

Gallego, O. F. 1997. Hallazgo de insectos Triásicos de la Argentina. Ameghiniana, 34, 511-516.

Giebel, C. G. A. 1856. Fauna der Vorwelt Bol. 2 Die Insekten und Spinnen der Vorwelt. F. V. Brodhaus (Ed.), Leipzig, $511 \mathrm{pp}$.

Gorochov, A. V. 1990a. Gryllida. In: Late Mesozoic insects of Eastern Transbaikalia. Trudy Paleontologicheskogo Instituta, Akademia Nauk, SSSR, 239, 210-214.

Gorochov, A .V. 1990b. New Genera and Species of Mesozoic Orthopteran Superfamily Hagloidea (Orthoptera) with uncertain Systematic Position. Novosti Philosophiki. i Sistematiki Kiev, 5, 32-35.

Gorochov, A. V. 1995. System and Evolution of the suborder Ensifera (Orthoptera). Russian Academy of Sciences. Proceedings of the Zoological Institute, Vol. 260, Part I, 3-224, Part II, 3-212.

Handlirsch, A. 1904. Über einige Insektenreste aus der Permformation Russlands. Memoir of the Saint Petersburg Academy of Sciences, 16 (5), 1-7.

Handlirsch, A. 1906. Die Fossilen Insekten und die Phylogenie der Rezenten Formen. Ein Handbuch für Paläontologie und Zoologie. Engelmann (Ed.), Leipzig, $640 \mathrm{pp}$.

Herbst, R. 1970. Estudio palinológico de la cuenca Ischigualasto-Villa Unión (Triásico) provincias de San Juan-La Rioja, Ameghiniana, 7, 83-97.
Kukalova-Peck, J. 1991. Fossil History and the Evolution of Hexapod Strutures. In: The Insects of Australia. (Eds. I. D. Naumann, P. B. Carne, J. F. Lawrence, E. S. Nielsen, J. P. Spradbery, R. W. Taylor, M. J. Whitten, and M. J. Littlejohn). Melbourne, University Press, Vol. 1, 141179.

Marquat, F. J. 1991. Ninfa de Miomóptero (Insecta) del Triásico de Mendoza, República Argentina. Revista Museo Historia Natural San Rafael, Mendoza, 11 (1), 313.

Martins-Neto, R. G. 1991. Sistemática dos Ensifera (Insecta, Orthopteroida) da Formação Santana, Cretáceo Inferior do Nordeste do Brasil. Acta Geológica Leopoldensia, 32 (14), 3-162.

Martins-Neto, R. G. e Rohn, R. 1996. Primeiro Registro de Inseto na Formação Rio do Rasto, Bacia do Paraná, com descrição de novo táxon. Geociências (São Paulo), 15 (1), 243-251.

Martynov, A. V. 1925. To the knowledge of fossil insects from Jurassic beds in turkestan. Bulletin of the Academy of Sciences, Lenningrad, 6 (19), 569-596.

Martynov, A. V. 1936. On some new data on the arthropods from Kuznetsk Basin. Izvetia Akademia Nauk SSSR. Ser. Biologiya, 6, 1251-1264.

Martynov, A. V. 1937. Liassic insects from Shurab and Kizyl-Kiya. Travaux de l'Institute de la Paeontologie, Academie des Sciences URSS, 7 (1), 1-231.

Martynova, O. M. 1958. New insects from the Permian and Mesozoic deposits of USSR. Materialy K. Osnovam Paleontologie, 2, 69-94.

Morel, E. M. 1994. El Triásico del Cerro Cacheuta, Mendoza (Argentina). Parte I: Geología, contenido paleoflorístico y cronoestratigrafía. Ameghiniana, 31 (2), 161-176.

Pinto, I. D. 1956. Artrópodes da Formação Santa Maria (Triássico Superior) do Rio Grande do Sul, com notícias sobre alguns restos vegetais. Boletim da Sociedade Brasileira de Geologia, São Paulo, 5 (1), 76-87.

Pinto, I. D. and Ornellas, L. 1974. A new insect Triassoblatta cargnini, Pinto et Ornellas, sp. n. a Triassic Blattoid from Santa Maria Formation, South Brazil. Anais da Academia Brasileira de Ciências, Rio de Janeiro, 46, 512-521.

Pinto, I. D. and Purper, I. 1978. A new genus and two species of plecopteran Insects from the Triassic of Argentina. Pesquisas, Universidade do Rio Grande do Sul, 10, 77-86.

Riek, E. F., 1976. A new collection of insects from the Upper Triassic of South Africa. Annals of the Natal Museum, Pietermaritzburg , 22 (3), 791-820.

Rivano, S. y Sepúlveda, P. 1991. Hoja Illapel Región de Coquimbo. Servicio Nacional de Geología y Minería, Carta Geológica de Chile, Santiago, 69, 1-132.

Rohdendorf, B. B. 1962. Fundamentals of Paleontology; Arthropoda, Tracheata, Chelicerata. Amerind Publishing CO. (ed.), New Delhi, Vol. 9, 1991, 894 pp.

Scherbakov, D. E. 1988. New Mesozoic Homoptera. Transactions of the Joint Soviet Mongolian Paleontological Expedition, 33, 60-63.

Sellards, E. H. 1909. Types of Permian Insects, Part. 3. 
Megasecoptera, Oryctoblattinidae and Protorthoptera. American Journal of Sciences, 4 (25), 154-173.

Sharov, A G. 1968. Phylogeny of the Orthopteroidea. Trudy Paleontologicheskogo Instituta, Moscow, 118, 1-251.

'Stipanicic, P. N. y Bonaparte, J. F. 1979. Cuenca Triásica de Ischigualasto-Villa Unión (Provincias de la Rioja y San Juan). In: Geología Regional Argentina. Academia Nacional de Ciencias, Córdoba, 1, 523-575.

Stipanicic, P. N., Herbst, R. y Bonetti, M. I. R. 1995. Floras Triásicas. In: Revisón y Actualización de la Obra Paleobotanica de Kurtz en la República Argentina (Eds. P. N. Stipanicic y M. A. Hünicken). Actas de la Academia Nacional de Ciencias, Córdoba, 11 (1-4), 127-184.

Storozhenko, S. Yu. 1997. New Triassic genera of the Family Atactophlebiidae (Grylloblattida). Far Eastern Entomologist, 40, 8.

Tillyard, R. J. 1922. Mesozoic Insects of Queensland. No 9.
Orthoptera and additions to the Protorthoptera, Odonata, Hemiptera and Planipennia. Proceedings of the Linnean Society, New South Wales, 47, 447-470.

Tillyard, R. J. 1925. Alleged Rhaetic Crane Flies. Nature, 116 (2923), 676-677.

Tillyard, R. J. 1926. Upper Permian insects of New South Wales. I. Introduction and the Order Hemiptera. Proceedings of the Linnean Society, New South Wales, 51, 1-30.

Wieland, G. R. 1925. Rhaetic crane flies from South America. American Journal of Sciences, New Haven, 9, 21-28.

Wieland, G. R. 1926. South America fossil insects discovery. American Journal of Sciences, New Haven, 12 (68), 130-135.

Zeuner, F. E. 1939. Fossil Orthoptera Ensifera. British Museum Natural History, London , 2 vols., 321 pp.

Manuscrito recibido: 2 de julio, 1998 Manuscrito aceptado: 29 de abril, 1999 